\title{
The Effects of Diversification Activities on the Technical Efficiency of Organic Farms in Switzerland, Austria, and Southern Germany
}

\author{
Sebastian Lakner ${ }^{1, *(\mathbb{D})}$, Stefan Kirchweger ${ }^{2}$, Daniel Hoop ${ }^{3}$, Bernhard Brümmer ${ }^{1}$ and \\ Jochen Kantelhardt ${ }^{2}$ \\ 1 Department of Agricultural Economics and Rural Development, University of Göttingen, \\ Platz der Göttinger Sieben 5, 37073 Göttingen, Germany; bbruemm@gwdg.de \\ 2 Institute of Agricultural and Forestry Economics, Department of Economics and Social Sciences, \\ University of Natural Resources and Life Sciences, Vienna, Feistmantelstraße 4, 1180 Vienna, Austria; \\ stefan.kirchweger@boku.ac.at (S.K.); jochen.kantelhardt@boku.ac.at (J.K.) \\ 3 Division for Competitiveness and System Evaluation, Agroscope, Tänikon 1, 8356 Ettenhausen, Switzerland; \\ daniel.hoop@agroscope.admin.ch \\ * Correspondence: slakner@gwdg.de; Tel.: +49-551-13788
}

Received: 5 March 2018; Accepted: 16 April 2018; Published: 23 April 2018

\begin{abstract}
The diversification of farms can be a result of multifunctional farming, however, in some cases at the cost of lower farm efficiency. In our paper we investigate the influence of para-agricultural diversification on productivity and the technical efficiency of organic farms in Austria, Switzerland, and Southern Germany. We show the benefits and drawbacks of diversification for organic farms, which go beyond the core agricultural production (para-agriculture). We do this by estimating a Stochastic Frontier (SF) combined with a metafrontier model. The data-set consists of bookkeeping data with 1704 observations in the years 2003 to 2005. Para-agricultural diversification activities have a significant effect on both productivity and technical efficiency of organic farms: The farm output in Austria and Switzerland is positively influenced by diversification, whereas we observe a rather small effect in Southern Germany. On the other hand, diversification can reduce farms' technical efficiency, as it is the case in Switzerland and Germany. Furthermore, our study confirms previous results that agricultural subsidies significantly influence the technical efficiency of organic farms. We also show expected changes of input use driven by increased farm diversification.
\end{abstract}

Keywords: technical efficiency; organic farming; grassland farming; farm diversification; para agriculture

\section{Introduction}

European agriculture is in major parts shaped by 'multifunctional farming' [1]. Multifunctional farming is of particular importance in regions with marginal production potential. The Alpine region is a prominent example with its extensive and often low-productive grassland use. But the relevance of multifunctional farming does not only depend on site condition, but also on farming systems. The literature highlights especially organic farming and its relevance as an example for [2] sustainable farming systems for multifunctionality. An important characteristic of multifunctional farming is the diversification of farms' economic activities [3]. Some activities, which do not belong to the core agricultural production but also employ farm resources like machinery, are of importance, since they allow farmers to explore new sources of income and, by spreading price and production risk upon different activities, to avoid a complete dependence on agricultural production. In Switzerland, such diversification activities are described with the term 'para-agriculture' and encompass direct 
marketing, rural tourism, and landscape maintenance [4,5]. Para-agricultural activities are of significant relevance in Switzerland, where they represent $4.4 \%$ of the total agricultural production value [6]. Flubacher [7] shows that organic dairy farms in Switzerland have a significantly higher engagement in para agriculture in comparison to conventional dairy farming. A labor-record in Switzerland documents that this trend on organic farms is also reflected in a significantly higher share of working time spent on para-agriculture [8]. However, para-agricultural activities are not only of relevance in Switzerland, but also in Austria and, to a smaller extent, in Germany. For instance, Recke, et al. [9] emphasize the importance of direct marketing for German agriculture, in particular with regard to organic farms.

A literature analysis reveals that the economic effects of diversification activities are broadly analyzed. Authors often apply statistical models, namely different kinds of regression models [10-16]. Propensity score matching is used as well [17]. Also the variety of research questions is broad: researchers investigate the impact of diversification on growth rates [12], risk reduction [10-12], farm assets [15], profits [16,17], and job generation [13]. Furthermore, Chavas and Di Falco [18] investigate the relation between risk and diversification by means of a stochastic production function [18]. Despite the broad research activities in the field, there are still open research questions. Current analysis mostly concentrates on individual countries and do not apply cross-country models. Furthermore, the literature review also reveals that the impact of diversification on farms' technical efficiency is only analyzed for the case of Swiss agriculture see $[5,19]$.

Organic farming is often discussed in the literature as a sustainable farming system [2], showing a higher degree of diversification [20]. The objective of our paper is to estimate the influence of agricultural diversification on technical efficiency of organic grassland farms in the Alpine region. By means of an efficiency analysis, we can also model the interaction between the core agricultural production and the diversification of farms. We apply a cross-country model, considering Austria, Switzerland, and Southern Germany. Since diversification activities are of particular importance for organic agriculture, we focus our analysis on organic farms. Farm diversification can occur within the core agricultural production or can go beyond core production. In this study, we investigate diversification activities going beyond the core agricultural production and describe them with the term para-agriculture. However, in contrast to the Swiss definition of para-agriculture, we widen the definition and additionally include farms' forest activities.

The manner and extent of para-agricultural diversification activities are influenced by factors such as natural site conditions, farm sizes, and farming systems [21-25]. Furthermore, agricultural policies significantly influence these types of activities. In the case of Austria, Switzerland, and Southern Germany, the impact of policy is of special importance, since policy is fundamentally steering in all three regions the conditions for organic farming [26]. The impact of policy is of general relevance in our study, since Switzerland does not belong to the European Union (EU) and has developed a fundamentally different political framework in comparison to Austria and Germany. Thus, in order to understand the economic effects of para-agriculture, it is necessary to properly consider in our cross-country analysis the respective policy situations. We do this by setting up three country-specific models, which we connect in a second step with a metafrontier approach.

\section{Background}

\subsection{Literature on Economic Effects of Farm Diversification}

Due to the flexible character of the term 'diversification' [27] we find different types of diversification in the literature. Most studies interpret diversification as the development of alternative income-earning opportunities for a farmer's household. The relation between agri-tourism, as one example of diversification beyond core agricultural production, and its effect on off-farm employment, has been the subject of several studies [16,17]. Katchova [14] concentrates on production-related diversification activities and subdivides her sample into livestock and crop diversifying farms, 
commodity diversifying farms, as well as specialized farms. Furthermore, the literature shows that studies also vary with regard to methodical approaches applied to the estimated economic effects of diversification. However, most studies apply various kinds of regression models: multiple regression models [14], random- and fixed-effect models [12], three-stage least squares regression models [10], and multinomial logit regression models $[11,13,15,16]$ are all used. Furthermore, the methods of both propensity score matching [17] and stochastic production functions are utilized [18].

The studies show that diversification activities are of significant economic relevance. However, modelling results and impacts show high variation between the types of diversification, as well as analyzed farm groups. Weiss and Thiele [12] could prove increased growth rates for German farms if the type of the diversification is closely connected to the farm products. In contrast to this, they find decreasing growth rates from diversification into unconnected products. They also show a reduced risk of income losses based on both diversification strategies [12]. Similar results are found by analyzing farms in the United States [10,11]. Barnes, Hansson, Manevska, Shrestha, and Thomson [15] investigate the structure of farm assets of farms in Sweden and Scotland, and conclude that diversification in both off- and on-farm activities results in a higher viability of farms. Similarly, Katchova [14] finds that farms with a high degree of diversification accumulate fewer assets than more specialized farms. She draws two main conclusions: firstly, diversified farms show lower efficiency because these farms support less-profitable activities by cross-subsidizing them with more profitable activities, or because they accept lower profits in return for risk reduction; secondly, diversified farms are more efficient when farm assets are considered as input factors [14]. In particular, agri-tourism maintains high profits on smaller farms. Furthermore, small farmers are able to increase their household income through off-farm employment $[16,17,24]$. Chavas and Di Falco [18] show that diversification may help to reduce risk in Ethiopian agriculture, but there are also economic trade-offs between diversification and specialization. Despite financial support by the Common Agricultural Policy (CAP), Chaplin et al. [13] finds relatively small levels of diversification activities in the Czech Republic, Hungary, and Poland, and as a result, the diversification will not reduce rural unemployment [13].

\subsection{Agricultural Policies in Germany, Austria, and Switzerland}

Switzerland, Austria, and Germany follow distinct agricultural policies: Even though German and Austrian agricultural policies differ in the details, both are embedded in the framework of the EU's CAP. In contrast to this, the agricultural policy of Switzerland is determined only by its national decision maker. During the last 25 years, both Switzerland and the EU have completed a series of reforms: the EU has liberalized their markets and policies by replacing price support with coupled and (after 2005) decoupled direct payments [28]; Switzerland already implemented such decoupled payments in 1993 [29]. Therefore, the type of direct payments differs during the period of investigation (2003/04 to 2005/06). The main details of the respective agricultural policies and their contributions to organic agriculture are as follows:

In Germany, direct payments play a major role. The coupled payments were provided as per-hectare payments for oil-seeds, grains, maize, protein-crops, flax, for set-asides in the crop-sector, and as per-animal slaughter premiums for cows, bulls, calves, suckler cows, sheep and goats [30]. Recent studies show that these coupled payments did influence farmers' decisions on production planning, input intensities and technical efficiency [31-33]. Besides the direct payments of Pillar I, farms were supported through the rural development programs (RD, see EU-regulation No. 1257/99 for the period 2000-2006) as Pillar II payments, which also included payments for organic agriculture [34].

In Austria, agricultural policy follows a similar system as in Germany, but slightly differing in objectives and implementation. In particular, Austria shifted a larger budget share and more programming efforts into the above mentioned RD programs (Pillar II) than other EU member states: In 2005, Austria's RD program had a budget share of about $58 \%$ of the total Austrian agricultural budget, which is significantly higher than the EU's average of $14 \%$ [35]. Besides having a focus on the $\mathrm{RD}$ program, the support of organic agriculture within this program is more pronounced in Austria. 
Switzerland enacted a number of major reforms to its national agricultural policy: direct payments were decoupled in 1993 and linked to environmental targets by the 'ecological performance record' in 1999. This policy regime continued to remain the same until the year 2013 [29]. The decoupled direct payments mainly consisted of general payments and ecological payments. The calculation of the general area payments for each farm were based on various criteria, including the production region and site conditions, and further specific payment top-ups for animals are added. The ecological payments are granted to farms for their environmental services and differ between arable land, extensively used grassland and traditional orchards. Within these payments, a premium for organic farming was paid [6].

Organic farming has been supported in the three countries for more than 20 years, and the share of organic farms has comparatively been increasing over time [36]. There are specific policies supporting organic farming in all three countries. Despite substantial country-specific differences in the policies themselves, the policies converge in their aim to foster the development of organic production [26]. An overview on the support measures are given in Table A1 in the Appendix A.

\subsection{Structure of Para-Agricultural Activities in Austria, Switzerland and Germany}

Table 1 presents the structure para-agricultural diversification activities of organic farms in the three case study countries. In this table, we counted all activities in all observations in para-agriculture, and thereby distinguished between farms which participate in only one activity ('specialized'), or which combine at least two activities ('combined'). In the three countries, most of the farms are focused on one activity in para-agriculture. In Austria (43.7\%), a larger share of farms combine different diversification activities. In Switzerland (27.2\%) and Germany (21.1\%), the share of farms combining different activities is lower, but still remarkable. The data also document the prevailing differences in the specific diversification strategies: Forestry plays an important role, especially in Germany and Austria, and direct marketing is important in Germany, whereas rental services are important in Switzerland.

Table 1. Share of organic farms with specialized or combined 'para-agricultural' diversification activities in Switzerland, Austria, and Germany.

\begin{tabular}{|c|c|c|c|c|c|c|}
\hline & \multicolumn{2}{|c|}{ Switzerland } & \multicolumn{2}{|c|}{ Austria } & \multicolumn{2}{|c|}{ Germany } \\
\hline & $\begin{array}{l}\text { Specialized }^{1} \\
\quad(n=485)\end{array}$ & $\begin{array}{c}\text { Combined }^{2} \\
(n=154)\end{array}$ & $\begin{array}{l}\text { Specialized }^{1} \\
\quad(n=412)\end{array}$ & $\begin{array}{l}\text { Combined }^{2} \\
(n=320)\end{array}$ & $\begin{array}{l}\text { Specialized }^{1} \\
\quad(n=251)\end{array}$ & $\begin{array}{c}\text { Combined }^{2} \\
\quad(n=67)\end{array}$ \\
\hline Forestry & 19.8 & 27.9 & 63.3 & 45.6 & 40.2 & 22.4 \\
\hline Agro-tourism & 0.8 & 3.2 & 14.8 & 14.7 & 0.0 & 0.0 \\
\hline Direct marketing & 8.0 & 19.5 & 7.3 & 10.9 & 39.8 & 59.7 \\
\hline Other para-agricultural activities ${ }^{3}$ & 2.9 & 3.9 & 1.2 & 3.4 & 4.4 & 0.0 \\
\hline Sum & 100.0 & 100.0 & 100.0 & 100.0 & 100.0 & 100.0 \\
\hline
\end{tabular}

Source: own calculation: ${ }^{1}$ 'Specialized para-agricultural farms' gain $>66 \%$ of their para-agricultural revenue from one activity; ${ }^{2}$ 'Combined farms' combine different activities between $33 \%$ and $66 \%$ of their para-agricultural revenue. We also categorize the 'combined farms' according to their most important diversification activity; ${ }^{3}$ 'Other activities' include alpine grassland farming, but also sawmills or small farm-dairies. Note: In Table 1, we evaluated the most important activity in para-agriculture in every farm in every year. Column 2 reads as follows: $19.8 \%$ of the specialized Swiss farms have forestry as the most important activity in para-agriculture. Column 3 reads as follows: $27.9 \%$ of the Swiss farms with different activities in para-agriculture have forestry as their most important activity.

\section{Materials and Methods}

\subsection{The Distance Frontier Model}

The data are given as joint input-categories but two separate outputs for agricultural production and diversification activities. Taking this data-structure with multiple outputs, we choose the distance frontier framework $[37,38]$. We accommodate to the different economic, structural and 
legal environments in the three countries by estimating a separate distance frontier for each country, followed by a metafrontier, which envelopes the three country frontier $[39,40]$.

Denote with $x_{t}$ the set of inputs, and with $P(x)$ the output set, i.e., all feasible output vectors $y \in \Re_{+}^{K}$ given $x_{t}$. Then, a technology can be described with an output distance function [37]

$$
D_{0}(x, y)=\inf _{\phi}\left\{\phi>0: \frac{\mathrm{y}}{\phi} \in \mathrm{P}(\mathrm{x})\right\}
$$

for all $x \in \Re_{+}^{K}$. The distance function $D_{0}(x, y)$ is nondecreasing, convex and linearly homogeneous in outputs, and decreasing and quasi-concave in inputs. The model is schematically described in Figure 1.

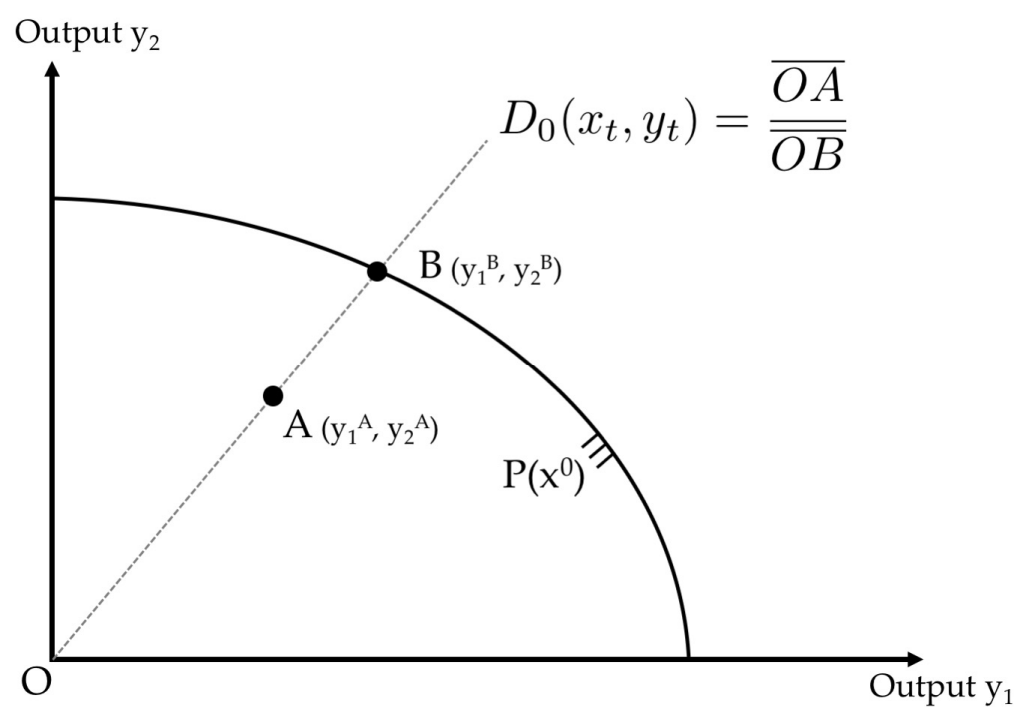

Figure 1. Output distance function with two outputs (see Färe and Primont, 1995 [37]).

The boundary of the output set is equivalent to the production possibility curve. The distance function $D_{0}(x, y)$ gives the relation of a given output vector $(\overline{O A}$ in Figure 1$)$ to the maximal feasible output with unchanged input mix $(\overline{O B})$.

One challenge in estimating the distance frontier econometrically is that the distance frontier under technical efficiency is equal to one. In our model, we have to consider two types of output, agricultural output and para-agricultural output. Hence, we derive the model with two outputs, agricultural output $\left(y_{1}\right)$ and para-agricultural output $\left(y_{2}\right)$. Taking logarithms, we can write our model in a simplified form:

$$
\ln \mathrm{D}_{0}\left(x,\left\{\frac{y_{1}}{y_{1}}, \frac{y_{2}}{y_{1}}\right\}\right)=-\ln y_{1}+\ln D_{0}(\cdot)
$$

$\ln D_{0}(\cdot)$ describes the relative distance between observed and maximal feasible output with given inputs, which leads to $\ln D_{0}(\cdot)<1$. In contrast, the efficiency measure of Farrell describes the maximal radial expansion of an output with inputs fixed (i.e., $\mathrm{TE}_{\text {Farrell }}>1$ ) [41]. So we can replace $D_{0}$ by the measure $1 / T E_{\mathrm{F}}$ :

$$
\ln \mathrm{D}_{0}\left(x,\left\{1, \frac{y_{2}}{y_{1}}\right\}\right)=-\ln y+\ln \left(\frac{1}{T E_{F}}\right)
$$

We replace the term $1 / T E_{F}$ by an exponential error-term $\exp (u)$ [38]. For the purpose of simplification, we rescale $T E_{i}$ as a reciprocal of Farrell's measure of TE such that $u_{i} \sim T E_{i}$ and $T E_{i}<1 .:$

$$
\ln \mathrm{D}_{0}\left(x,\left\{1, \frac{y_{2}}{y_{1}}\right\}\right)=-\ln y-u
$$


Reformulation and introduction of a white noise error term $v$ brings a form quite close to a stochastic production frontier [42]:

$$
\ln y_{1}=f\left(1 ; \frac{y_{m}}{y_{1}} ; x_{j}\right)+v-u
$$

$f$ represents the functional form that has to be determined. We started with a translog functional form and we tested for a Cobb-Douglas functional form. The first step is the estimation of group-specific frontier for the groups $G=1,2,3$ which are Austria, Switzerland, and Germany.

The estimation of the parameters of the stochastic frontier model can be based on maximum-likelihood estimates. The first error-term $v_{i}$ describes stochastic effects that are beyond the farmer's control and are defined as independently and identically distributed as $N\left(0, \sigma_{v}^{2}\right)$ [42]. The inefficiency term $u$ is a non-negative amount that describes the inefficiency that is under the farmer's control. This term $u$ has a half-normal distribution $u_{i} \sim N^{+}\left(0, \sigma_{u}{ }^{2}\right)$, this assumption allows the estimation of the heteroscedasticity model, which captures the impacts of a set of explanatory $j$ variables $z$ for technical efficiency.

The model is defined as follows:

$$
\sigma_{u_{i}}^{2}=\exp \left\{z_{j} \rho_{j}\right\}
$$

with $z_{j}$ as a set of explanatory variables, which explain technical (in)efficiency [43,44]. If the estimated parameter $\rho$ is positive (negative), the corresponding variable has a negative (positive) influence on technical efficiency.

Since we are estimating the efficiency of farms in three countries we apply the stochastic meta-frontier model by firstly estimating group efficiency (TE) within the three countries and then estimating a joint deterministic metafrontier, which envelope the country-frontiers $[45,46]$. The metafrontier is defined as follows:

$$
-\ln y_{1}^{*}=f\left(x_{j}^{*},\left\{1, \frac{y_{m}^{*}}{y_{1}^{*}}\right\}\right)
$$

with the outputs $y$ and inputs $x$ of the metafrontier *. The model is a deterministic model, since we already consider stochastic effects in the group-frontiers. The parameters are produced by a linear optimization. In the final estimation of the metafrontier, we use a translog functional form as presented in Equation (10).

The model is a deterministic model and the parameters are produced by a linear optimization. We use two methods to estimate the parameters of the metafrontier, namely (1) the optimization by minimizing the absolute deviation, and (2) the minimization of the squared deviation [45].

The combination of group-frontiers $(G=1,2,3)$ and the metafrontier* allows to estimate the general differences in technology, which are captured by the model output, the 'Meta-Technology Ratio' (MTR). The MTR describes the technological differences of the group-frontiers used in the three countries to the joint technology (represented by the metafrontier). The total efficiency $\mathrm{TE}^{*}$ is defined as a product of the group- or country-specific efficiency $\mathrm{TE}^{\mathrm{G}}$, produced by the distance frontier model and the MTR:

$$
T E_{i t}^{*}=T E_{i t}^{G} \times M T R_{i t}
$$

The distance function and metafrontier are estimated using sfamb [47] for OxMetrics 7.1 [48], the metafrontier is simulated by 5000 times bootstrapping to generate estimates of the standard-errors.

Based on the estimation results we can calculate the potential effect of a $1 \%$-increase of para-agriculture, which is usually followed by an adjustment of the optimal input mix of the farms. Following Brümmer et al. (2006) [49], we assume simple static profit maximizing behavior, the resulting optimization exercise involves $\sum_{m} \mathrm{p}_{\mathrm{m}} y_{m}-\sum_{j} w_{j} x_{j}$, subject to the frontier technology $D_{0}=1$, where $p$ 
and $w$ are the vectors of product prices and input prices, respectively. The first order conditions of the corresponding with respect to a specific input $j$ yields $w_{j} x_{j}=-\lambda \frac{\partial D_{0}}{\partial x_{j}} \frac{x_{j}}{D_{0}}$, where $\lambda$ is the Lagrangian multiplier. Summing up over all $j$ first order conditions for the inputs, we have $\sum w_{j} x_{j}=-\lambda \sum \frac{\partial D_{0}}{\partial x_{j}} \frac{x_{j}}{D_{0}}$. The summand corresponds to the $\varepsilon_{k}$, the $j$ th input elasticity of the output distance function DO. The summation of the input distance elasticities over $j$ yields the (negative of the) scale elasticity, $\varepsilon$. The cost share of input $\mathrm{j}$ is defined as $S_{j}=\frac{w_{j} x_{j}}{\sum w_{k} x_{k}}$. Substituting the above first order conditions in both numerator and denominator of the cost share definition gives the shadow cost share $S_{j}^{*}$ of input $\mathrm{k}: S_{j}^{*}=\frac{-\lambda \frac{\partial \ln D_{0}}{\partial \ln x_{j}}}{-\lambda \sum \frac{\partial \ln D_{0}}{\partial \ln x_{k}}}=\frac{\varepsilon_{j}}{\varepsilon}$.

Assuming a static profit-maximization, the adjustment is expressed as the change of the shadow cost shares followed by a relative change in the revenue from para-agriculture $y_{2}$ (Equation (9)):

$$
\frac{\partial S_{J}^{*}}{\partial \ln y_{2}}=\frac{\partial\left(\frac{\varepsilon_{j}}{\varepsilon}\right)}{\partial \ln y_{2}}=\frac{\frac{\partial \varepsilon_{j}}{\partial \ln y_{2}} \varepsilon-\frac{\partial \varepsilon}{\partial \ln y_{2}} \varepsilon_{j}}{\varepsilon^{2}}
$$

In Equation (9), $S_{j}^{*}$ denotes the shadow cost share of input $j, \varepsilon_{j}$ the input distance elasticity of input $x_{j}$, and $\varepsilon$ the scale elasticity.

\subsection{Data Description and Adjustment}

We use bookkeeping data from organic mixed and grassland-Farms in the years 2003, 2004, and 2005. In Germany the data refer to the bookkeeping period from July to June of the following year in the respective years 2003/04, 2004/05, and 2005/06, in Switzerland and Austria the data are organized in calendar years. The German data contains bookkeeping data from 106 farms in Bavaria and Baden-Württemberg, which was provided by Land Data GmbH. The Swiss data is taken from the Farm Accounting Data Network (F.A.D.N.) in Switzerland and contains 213 organic farms. The Austrian data is taken from the voluntarily bookkeeping farm network of the Ministry for Agriculture, Forestry, Environment and Water in Austria (BMLFUW) and contains 244 organic farms. As 'outliers' we define farms with any input or output value greater than the mean value plus three standard-deviations. This leads to a balanced panel data-set of 1689 observations, outliers are deleted from the data.

In Switzerland, para-agriculture describes activities, which are near to the agricultural production process and make a yearly revenue between 5000 and 250,000 Swiss Francs [4,5]. In order to ensure comparability between German, Austrian, and Swiss bookkeeping's accountancy, rules were harmonized by using the same output-categories: Agricultural output $\left(y_{1}\right)$ contains all revenues from plant and animal production while para-agricultural output $\left(y_{2}\right)$ contains revenues from activities closely related to agriculture, such as direct marketing, agro tourism, wine production, services or renting out land, machinery or buildings. Furthermore, we include aggregated payments for organic farming and other ecological objectives in the three countries as 'environmental payments' $\left(z_{2}\right)$. We summarized the remaining types of the agricultural payments as 'other payments' $\left(z_{3}\right)$, which are mainly the per-hectare and per-animal direct payments.

In the Swiss F.A.D.N. data, farm and residential buildings are regarded as part of the farm enterprise, i.e., also the assets and costs of the residential buildings have to be included in the accounting. This unique characteristic of the Swiss data inflates the contribution of para-agricultural output to farm income compared with German and Austrian data. About 52\% of the output of para-agriculture stems from artificial rent payments of the farmer's family to the farm, the remaining $48 \%$ of para-agricultural revenue can be interpreted as para-agriculture activities that create farm income. We eliminate this effect from the Swiss data to ensure consistency by subtracting imputed rental payments from the farmer's family to the farm in order to compensate for all costs that arise from residential buildings. 
The data are deflated using the base year 2000 and official price indices from each country. Since trade for inputs and outputs are subject to tariffs between the EU and Switzerland, the exchange-rate might in some cases not fully reflect scarcities or input shadow-prices in Switzerland. Therefore, price adjustments are done for the single inputs and outputs of the Swiss data-set in order to reflect not only the currency exchange but also the diverging shadow-prices for different inputs in Switzerland.

The applied output distance-function is defined as follows:

$$
\begin{aligned}
-\ln y_{1}=\alpha_{0}^{G}+\quad \sum_{m}^{1} \alpha_{m}^{G} \ln \frac{y_{m i t}}{y_{1}}+\frac{1}{2} \sum_{m=2}^{1} \sum_{n=2}^{1} \alpha_{m n}^{G} \ln \frac{y_{m i t}}{y_{1}} \ln \frac{y_{n i t}}{y_{1}}+\sum_{j=1}^{4} \beta_{j}^{G} \ln x_{j i t} \\
+\frac{1}{2} \sum_{j=1}^{4} \sum_{k=1}^{4} \beta_{j k}^{G} \ln x_{j i t} \ln x_{k i t}+\sum_{m=2}^{1} \sum_{j=1}^{4} \delta_{m j}^{G} \ln \frac{y_{m i t}}{y_{1}} \ln x_{j i t}+\beta_{t}^{G} \mathbf{t}+\frac{1}{2} \beta_{t t}^{G} t^{2} \\
+\mathbf{v}_{i t}-u_{i t}
\end{aligned}
$$

with the output $y$ with $m=1$ for agricultural output and $m=2$ for output from para-agriculture, and the $x$ inputs $j=1,2,3,4$ for variable costs, capital, labor and land and with $t$ for the year. The parameters $\alpha, \beta, \delta$ are to be estimated. The parameter $\alpha$ describes the contribution of the outputs from para-agriculture to the agricultural output. The parameter $\beta$ describes the impact of the inputs $j$ on the agricultural output. The parameter $\delta$ describes the influence of the interaction of $y_{2}$ and the inputs $x_{j}$ on the agricultural output. $\beta_{t}$ represents the technical change over time-periods $t=1,2,3$ in the years from 2003 to 2005.

We assume that farm structure is fixed or quasi fixed in the short run, since labor is a given factor for family farms and the structure of farm-capital cannot be changed without substantial costs of adjustment. Kumbhakar [50] shows that with a completely flexible input choice, endogeneity is one problem to be addressed for the model choice. However, this is not the case for our group of farms and our very short panel data-set. Therefore, we do not apply a model capturing a potential endogeneity. Table 2 presents the summary of statistics:

Table 2. Description of the variable used in the model.

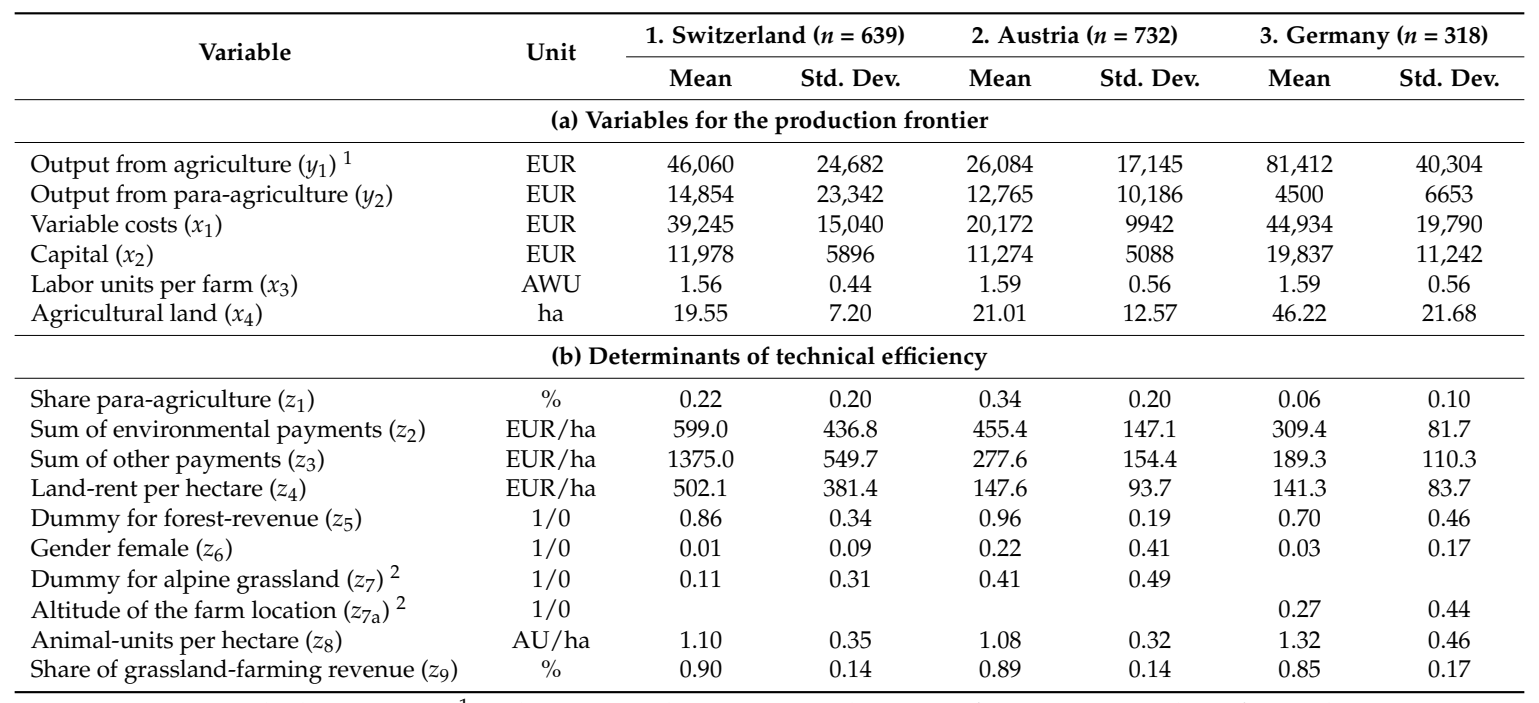

Source: own calculation. Note: ${ }^{1}$ In the German data-set we set the output from para-agriculture for 46 observations ( $14 \%$ of the sample) from zero to one EUR, based on the assumption that a German farm uses a minimum level of diversification; ${ }^{2}$ In Switzerland and Austria we include a dummy for farms with the use of alpine grassland. Comparable information for Germany is not available. Therefore, we use a dummy for farms above $600 \mathrm{~m}$, which is not exactly the same information, but which however might reflect a similar farm characteristic of producing in locations with lower production potential.

The statistical summary in Table 2 of the data shows a similar farm structure in Austria and Switzerland, in contrast to the farms structures in Southern Germany. Similarities between means can be found for the total output from para-agriculture, labor units per farm, agricultural land and the 
animal-units per hectare. The output from agriculture is highest in Southern Germany and significantly smaller in Switzerland and Austria. The relative contribution of para-agriculture $\left(z_{1}\right)$ is highest in Austria with $34 \%$ of the total farm revenue and moderate in Switzerland with $22 \%$, but still substantially higher than the share of para-agriculture in the Swiss conventional sector, where the average share is about $3.2 \%$ [19]. The average contribution of para-agriculture in Germany is low in comparison, at roughly $6 \%$ of the total farm revenue.

\section{Results}

\subsection{Production Structure and Efficiency}

Table 3 presents the relevant tests that support the choice of the applied model:

Table 3. Results for different tests of model quality.

\begin{tabular}{|c|c|c|c|c|}
\hline \multirow{2}{*}{ Null-Hypothesis } & \multicolumn{3}{|c|}{ Test-Value } & \multirow{2}{*}{ Critical Value } \\
\hline & Switzerland & Austria & Germany & \\
\hline LLR-test for joint estimation & & $529.01 * *$ & & 108.65 \\
\hline $\begin{array}{l}\text { H1: No inefficiency } \\
\rho_{j}=0, j=5,6, \ldots, 13\end{array}$ & $373.96^{* *}$ & $146.09^{* *}$ & $198.47^{* *}$ & 3.84 \\
\hline $\begin{array}{l}\text { H2: CD-production function } \\
\beta_{j j}=\beta_{j k}=\alpha_{m m}=\alpha_{m n}=\delta_{m j}=0\end{array}$ & $137.83 * *$ & $532.93 * *$ & $42.55^{* *}$ & 33.92 \\
\hline $\begin{array}{l}\text { H3: Linear homogeneity (constant returns to scale) } \\
\sum \beta_{j}=1 ; \sum \beta_{j k}=0 ; \sum \delta_{m j}=0 \text { for } j=1,2,3,4\end{array}$ & 1069.36 ** & $2221.47^{* *}$ & $1752.01 * *$ & 11.07 \\
\hline H4: No Heteroscedasticity $\rho_{j}=0, j=1,2, \ldots, 13$ & $392.29^{* *}$ & $253.35^{* *}$ & $251.09^{* *}$ & 26.30 \\
\hline
\end{tabular}

Source: own calculations. ${ }^{+}$: Critical Value for $\mathrm{H}^{1}$ according to KODDE and PALM (1986) [51], the other critical values are taken from the Chi-squared-distribution. ${ }^{* * *} / * * *$ significant for $p<0.01 / 0.05 / 0.1$.

We did a joint stochastic frontier estimation of the three groups (countries) and used the likelihood value to test for a joint representation by one SF, which was rejected. In H1, we tested a stochastic production function without an efficiency term, which was rejected. In $\mathrm{H} 2$, the functional form of a Cobb-Douglas SF was tested against the more flexible translog form, which was rejected. In $\mathrm{H} 3$, we tested linear homogeneity and in $\mathrm{H} 4$ we tested the model without the application of the heteroscedasticity model. Both tests were rejected. We found minor problems with regards to the monotonicity requirement for the variables labor and land in Austria, and for labor in Switzerland.

The estimated coefficients for the country specific distance-frontiers and the joint metafrontier for the three countries are presented in Table 4 . The first order coefficients $\beta_{1,2,3,4}$ are interpreted as input elasticities to agricultural output $\left(y_{1}\right)$. The coefficient $\alpha_{1}$ shows the contribution of para-agriculture $\left(y_{2}\right)$ to total output:

Table 4. Estimated coefficients of the distance frontier.

\begin{tabular}{lccccc}
\hline \multirow{2}{*}{ Variable } & \multicolumn{3}{c}{ Country Specific Frontier } & \multicolumn{2}{c}{ Metafrontier } \\
\cline { 2 - 6 } & Switzerland & Austria & Germany & Meta 1 & Meta 2 \\
\hline$\alpha_{0}$ Constant & $0.2025^{* * *}$ & $0.3218^{* * *}$ & $0.1469^{* * *}$ & $0.3935^{* * *}$ & $0.5917^{* * *}$ \\
$\alpha_{1}$ Output para-agriculture & $0.1116^{* * *}$ & $0.2965^{* * *}$ & $0.0310^{* * *}$ & $0.2685^{* * *}$ & $0.2002^{* * *}$ \\
$\beta_{1}$ Variable Input Costs & $-0.6516^{* * *}$ & $-0.6552^{* * *}$ & $-0.4722^{* * *}$ & $-0.6566^{* * *}$ & $-0.6531^{* * *}$ \\
$\beta_{2}$ Depreciation (as Capital) & $-0.1372^{* * *}$ & $-0.1344^{* * *}$ & $-0.2298^{* * *}$ & $-0.1328^{* * *}$ & $-0.0736^{* * *}$ \\
$\beta_{3}$ Labor-Units & -0.0957 & $-0.0925^{* * *}$ & $-0.3141^{* * *}$ & $-0.1080^{* * *}$ & -0.0634 \\
$\beta_{4}$ Agricultural Land & $-0.1782^{* * *}$ & $-0.0961^{* * *}$ & $-0.1069^{* *}$ & $-0.0862^{* * *}$ & $-0.0878^{* * *}$ \\
$\beta_{t}$ Technical change & -0.0234 & -0.0166 & -0.0091 & -0.0092 & -0.0030 \\
{$[\ldots$ ] } & The estimated results for the cross-terms are left out for simplification reason \\
\hline
\end{tabular}

Source: own calculation; 'stochastic frontier analysis using ModelBase (sfamb)' [47] for OxMetrics 7.1 [48], $* * * / * * *$ significant for $p<0.01 / 0.05 / 0.1$. Insignificant coefficients are displayed in grey. 
Diversification (Para-agriculture, $\alpha_{1}$ ) shows a substantial contribution to total output in Austria and a moderate contribution in Switzerland [52]. For Austria, this elasticity (0.30) is in accordance with the revenue share of diversification of $34 \%$ (see Table 2). The contribution of para-agriculture in Switzerland is smaller with an estimated coefficient of 0.11 . If we assume revenue maximization, revenue share of the outputs should be equal to the output distance elasticities [5,38]. However, for Switzerland, the output distance elasticity (0.11) is substantially below the share of revenues of para-agriculture to total revenues (22\%), as in [5]. The estimated output elasticity for para-agriculture is still comparatively high in the organic farming sector: Mamardashvili, Bokusheva and Schmid [5] estimate an output-elasticity of 0.006 for conventional Swiss farms, with a lower output-share of para-agriculture of $3 \%$, which documents the specific importance of diversification in organic farming systems. In Germany, the output elasticity of para-agriculture to total output is low.

Variable input costs $\left(\beta_{1}\right)$ are by far the most important inputs in the three countries: An increase of variable inputs by $1 \%$, would increase agricultural output by ca. $0.65 \%$ in Austria and Switzerland and by $0.47 \%$ in Germany. The other parameters show some differences in the production structure: In Germany, capital $\left(\beta_{2}\right)$ and labor $\left(\beta_{3}\right)$ contribute $0.23 \%$ and $0.31 \%$ respectively to agricultural output, whereas the output elasticities of these inputs are substantially lower in Austria and Switzerland. This highlights the importance, especially of labor forces, for German organic farms. In contrast to this, land has a high output elasticity in Switzerland (represented by $\beta_{4}$ ): An increase of the input land by $1 \%$ increases agricultural output by $0.18 \%$, whereas this elasticity is substantially lower in Germany and Austria at $0.11 \%$ and $0.10 \%$. Flubacher [7] also found an output elasticity of land of 0.19 for organic dairy farms for the period from 2009 to 2011.

The estimated group technical efficiency $\left(\mathrm{TE}^{\mathrm{G}}\right)$, the meta technology ratio (MTR), and the total efficiency $\left(\mathrm{TE}^{*}\right)$ are presented in Table 5:

Table 5. Technical efficiency, meta technology ratio and total efficiency of organic farms in Switzerland, Austria, and Southern Germany.

\begin{tabular}{cccc}
\hline & $\begin{array}{c}\text { Countries Technical } \\
\text { Efficiency }\left(\mathbf{T E}^{\mathrm{G}}\right)\end{array}$ & $\begin{array}{c}\text { Meta-Technology Ratio } \\
\text { (MTR) }\end{array}$ & Total Efficiency $\left(\mathrm{TE}^{*}\right)$ \\
\hline Switzerland & 0.7814 & 0.6873 & 0.5383 \\
Austria & 0.7598 & 0.7497 & 0.5797 \\
Southern Germany & 0.8505 & 0.6487 & 0.5567 \\
\hline
\end{tabular}

Source: own calculation. We took the meta technology ratio (MTR)-scores from the second metafrontier model, which minimizes the sum of squared deviations, see Section 3.2.

The technical efficiency scores $\left(\mathrm{TE}^{\mathrm{G}}\right)$ are typically interpreted as the individual farm efficiency level relative to their own technology, which is modelled by the stochastic frontier: Organic farms in Southern Germany show the highest efficiency level relative to their own technology, followed by Swiss and Austrian organic farms. The concept of meta-technology ratio (MTR) is interpreted as the difference between the different group (or country) technologies. For the MTR, organic farms in Austria show the most efficient performance, whereas farms in Switzerland and Southern Germany apply less efficient technology compared to the metafrontier. The results for the total efficiency (TE*) (Equation (10)) reveal that Austrian farms are the most efficiency across the different technology groups, followed by German farms (TE*: $-2.3 \%$-points) and Swiss farms ( $-4.1 \%$-points).

If we discuss the estimation results of the country specific group frontier, the estimation shows German farms to be more efficient than Swiss and Austrian farms relative to their country specific technology. However, we need to mention the structural differences between Germany and the two alpine countries Austria and Switzerland (Table 2), which restrict the interpretation of pure TE-results. In addition to this, German organic farms are less diversified than Austrian and Swiss farms.

We calculated the returns to scale (RTS) per farm by including all estimated parameters. The distribution of the estimated RTS-results within the three countries are presented in Figure 2. 
(a) Switzerland

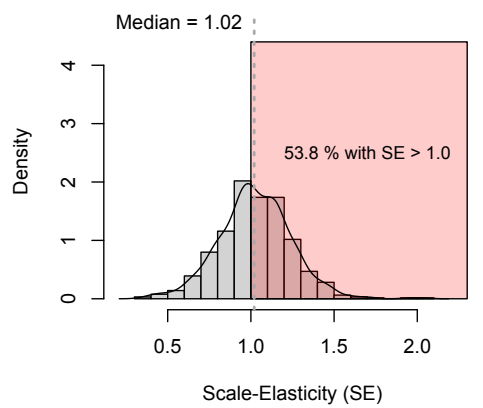

(b) Austria

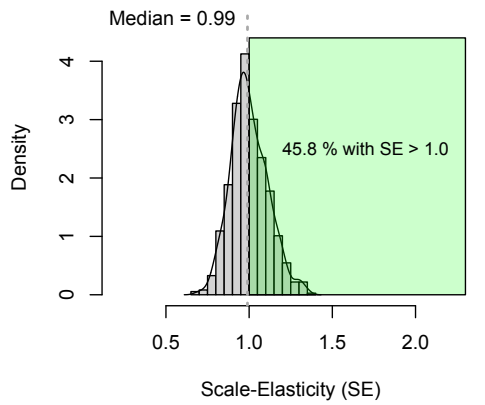

(c) Germany

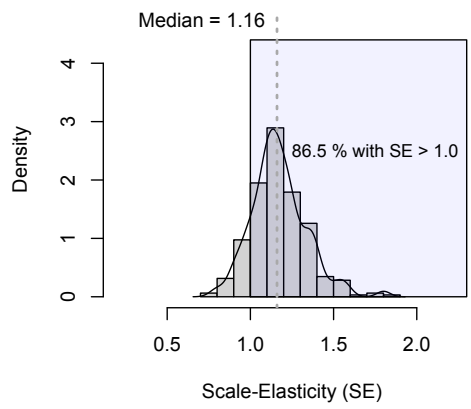

Figure 2. Returns to scale (RTS) on organic farms in (a) Switzerland (b) Austria and (c) Germany. Source: own calculation, number of observations in Switzerland: 639, in Austria: 732 and in Germany: 318.

Figure 2 reveals that $86.5 \%$ of the German farms produce with increasing RTS. Swiss and Austrian organic farms tend to work with almost constant RTS: $53.8 \%(\mathrm{CH})$ and $45.8 \%$ (AT) of the farms in the two countries show returns to scale above 1.0. The results indicate a higher probability for structural change in Southern Germany, whereas fewer organic farms in Switzerland and Austria would profit from farm growth. In the high alpine regions of Switzerland and Austria, there seems to be less potential to realize profits from scale effects due to large farm sizes and large factor endowments. Another factor to explain scale differences might be the share of high alpine grassland, which is less productive due to altitude. Organic farms in Austria have an average share of $42 \%$ of this grassland type. Even in Switzerland, this grassland type has a share of $11 \%$, and farms with high alpine grassland also show a lower TE (see Table 7 in Section 4.3 below). Both factors support the hypothesis that alpine farms cannot fully compete against lowland farms with high RTS.

\subsection{Adjustments of the Input Mix with Increasing Para-Agriculture}

The following Table 6 presents the elasticities of inputs subject to changing output of para-agriculture $y^{2}$ (see Equation (9)).

Table 6. Elasticity of shadow cost shares with respect to para-agriculture.

\begin{tabular}{lccc}
\hline & Switzerland & Austria & Germany \\
\hline Intermediate input cost share & -0.038 & -0.034 & 0.007 \\
Capital cost share & 0.027 & -0.007 & 0.005 \\
Labor cost share & 0.016 & -0.000 & -0.009 \\
Land cost share & -0.004 & 0.041 & -0.002 \\
\hline
\end{tabular}

Source: own calculation.

The results show the change in the shadow cost shares of each input following a relative increase in $y_{2}$ (revenue from para-agriculture) for an average farm in each country. These elasticities are negligible for Germany due to the relatively low initial share of para-agriculture. A marginal increase in para-agriculture would not require a huge adjustment in the organization of an average farm in Germany.

This is different in Austria and Switzerland, where the initial shares of para-agriculture are substantially higher. Both countries share a common feature: Expanding para-agriculture reduces the shadow cost share of intermediate inputs, as they are linked to core agricultural production. Since an increase in para-agriculture necessarily implies a decrease in core agriculture, the overall input use of the average farm becomes less intensive in intermediate inputs. The factors that increase in their shadow cost share differs between the two countries. 
In Switzerland, the shadow cost shares of capital and labor increase, because Swiss para-agriculture is dominated by capital and labor intensive activities such as direct marketing, rural tourism, and services (i.e., renting out machinery or buildings, see Table 1). Hence, a farm that expands its para-agricultural production will reduce costs for intermediate inputs in agriculture, and therefore produce less intensively. On the other hand, such a farm will increase capital and labor use, which can be utilized in both agricultural and para-agricultural activities. Therefore, within the farms, there is competition in the use of labor and capital for both agriculture and para-agriculture. On the other hand, economies of scope will be achieved if both factors can be applied efficiently together.

In Austria, an increase of para-agriculture leads to an increase in the shadow cost share of land. Para-agriculture in Austria mainly consists of agro-tourism and forestry, which rely, in particular with regard to forestry, on the availability of land. In contrast to Switzerland, the expansion of rural tourism in Austria seems to be based on additional land. Therefore, with a given input-structure, farms can save some intermediate input costs, and use land less intensively. Capital and labor will decrease.

\subsection{Determinants of Technical Efficiency}

Table 7 presents the determinants of technical (in-) efficiency.

Table 7. Determinants of technical (in-) efficiency ${ }^{1}$.

\begin{tabular}{lccc}
\hline \multicolumn{1}{c}{ Variable } & Switzerland & Austria & Germany \\
\hline Share para-agriculture (\%) & $1.2485^{* * *}$ & $-1.3875^{* * *}$ & $4.3546^{* * *}$ \\
Environmental payments (EUR/ha) & $0.4939^{* * *}$ & 0.0660 & $1.0757^{* * *}$ \\
Other payments (EUR/ha) & $0.5147^{* * *}$ & $0.2057^{* * *}$ & $0.5420^{* * *}$ \\
Level of land-rent (EUR/ha) & $-0.1244^{* * *}$ & $-0.1345^{* * *}$ & -0.1305 \\
Existing forestry activity (0/1) & $-0.1110^{* * *}$ & 0.2240 & -0.1909 \\
Gender of farm manager (female $=1)$ & $-0.6409^{* * *}$ & 0.0692 & $0.7938^{* * *}$ \\
Dummy for alpine grassland (0/1) & $0.4217^{* * *}$ & 0.0706 & $-1.0553^{* * *}$ \\
Altitude-zone of the farm (above 600 $\mathrm{m}=1)^{2}$ & & & $-0.8835^{* * *}$ \\
Land-use intensity (AU/ha) & $-2.6836^{* * *}$ & $-0.5481^{* * *}$ & $-1.1891^{* * *}$ \\
Share of revenue grassland farming (\%) & $1.6496^{* * *}$ & $-0.5673^{* * *}$ & \\
\multicolumn{2}{c}{ For simplification, not all coefficients of the model are presented } \\
\hline
\end{tabular}

Source: own calculation with sfamb [48] for OxMetrics 7.1 [49], *** ${ }^{* *} / *$ significant for $p<0.01 / 0.05 / 0.1$. Note:

${ }^{1}$ The estimated parameters capture the impact on inefficiency. A negative (positive) parameter should be interpreted as positive (negative) impact on TE. ${ }^{2}$ For Germany we used a dummy for the altitude level $z_{7 b}$, since the data-set does not contain information as to whether the farm would use alpine grassland. Insignificant coefficients are displayed in grey.

The estimated coefficient of 1.25 indicates that with an increased share of para-agriculture, farms' technical efficiency decreases in Switzerland $[5,53]$. The result in Germany is even more pronounced (4.35). In contrast, diversification (para-agriculture) increases farm TE for Austrian farms, which can be explained by the economic significance of these activities: the output share of diversification is on Austrian farms an average of $32 \%$. The results of Swiss and German farms confirm the expected effects of diversification: farm diversification comes at the cost of lower technical efficiency in the different production activities. On the one hand, para-agriculture contributes to higher farm revenue and therefore shows a stabilizing effect on the farm. This strategy of diversification could be recommended for risk-averse farmers. On the other hand, farmers have to give up profits from specialization and work at lower TE-levels. The TE-results for Austrian' farms suggest that para-agricultural activities are complementary to core production activities, using factors that are underemployed in agriculture (such as the labor force of a partner) by means of diversification activities. This might explain the finding that a high share of para-agriculture increases TE.

Direct payments show a reducing effect on technical efficiency in the three countries, and the environmental payments in Germany and Switzerland also show negative effects on TE. In practice there are multiple options to combine payments for organic farming with other types of agri-environmental payments [54-57], which also coincide with reduced productivity and/or a 
reduced yield. Therefore, the TE-reducing effect of high environmental payments per hectare can be partly explained by the combination of different agri-environmental measures. Additionally, especially in Switzerland, higher payment rates can be observed for "steep grassland" or "high alpine grassland". For some of these features, environmental payments are increased. Hence, environmental payments partly reflect natural disadvantages, which might also explain inefficiency.

The influence of land rent on technical efficiency is positive in Austria and Switzerland and reflects different land quality. Farms with a female farm manager achieve higher TE-values in Switzerland and lower values in Germany. The share of female farmers in the data-set is very low, therefore this result has to be treated with caution. Farms using alpine grassland have lower technical efficiency in Switzerland and Austria. In Germany, farms at an altitude above $600 \mathrm{~m}$ show higher technical efficiency. The influence of land-use intensity is positive as expected, which is in line with Lakner, von Cramon-Taubadel and Brümmer's [43] finding in the case of German organic grassland farms. Specialization (as the share of revenue of grassland-farming) represents the opposite of diversification: farms with a high degree of specialization are more efficient in Austria and Germany, but less efficient in Switzerland.

\section{Discussion}

The results of our study reveal significant production and efficiency differences of organic farms in Austria, Switzerland, and Southern Germany. In relation to their own frontier, southern German organic farms show a slightly better result (TE: 0.85), closely followed by Switzerland (0.78) and Austria (0.76), which can be explained by the larger technological heterogeneity in both countries in comparison to Southern Germany, where mountain-regions are of minor importance. In contrast, the joint metafrontier is mainly driven by Austrian farms (MTR: 0.75), followed by Switzerland (0.69), and Germany (0.65). The total efficiency is highest in Austria (TE*: 0.58), whereas Germany (0.56) and Switzerland (0.54) lag slightly behind.

The literature reveals that farmers show stronger participation rates in agri-environmental schemes in marginal production regions with unfavorable site conditions, as shown in the case of Austrian farms [58]. In such (in our case mostly alpine) regions, agricultural productivity is comparably low, and farmers are often prepared to increase revenues by making use of agri-environmental payments as comprehensively as possible. Such strategies contribute to a further reduction of agricultural yield potentials-especially if environmental programs are combined. Therefore, farms participating in agri-environmental schemes tend to be even less efficient. This might be true for natural disadvantages as well, since they are incorporated into environmental payments in Switzerland.

Similar model-approaches are described with respect to diversification, as it correlates with the location of the farm [21]. The different site conditions in the three study regions seem to be substantially driving the results. Namely the high values for diversification output, the level of land-rents (indicating soil quality), and the scope of environmental and further subsidies in combination with a lower technical efficiency in Austria and Switzerland.

For future research, it is necessary to better analyze the influence of structural differences on efficiency results across countries. Recent studies suggest to complement productivity analysis with matching, which is an appropriate methodology to cope with such structural heterogeneity and selection bias $[59,60]$. Therefore, a future task will be to integrate a matching approach into our analysis in order to control the structural differences between the countries.

Para-agriculture in the context of this study is interpreted as one option for farmers to diversify a farm beyond core agricultural production. Similar studies for the conventional sector show that the share of similar diversification activities in Switzerland is lower [5,7], which highlights the importance of diversification in the organic sector. Organic farms are by definition more diverse within their agricultural activities [8,9]. This study documents that the diversification activities beyond core agricultural production (based on the Swiss' concept of 'para-agriculture') are more pronounced, and also provide opportunities for farm income in rural areas. Organic farms are by 
nature closer to customers through direct marketing [9], therefore other diversification activities fit to a customer oriented diversification. Our studies also documents that the diversification activities beyond farming are varied in type and extent in the three investigated regions (as in Table 1), with differing consequences for farm outputs and efficiency levels (Table 5) and for input mix (Table 6). Furthermore, diversification is of special importance for Austrian farms, since the share of revenues from diversification has a positive impact on farm technical efficiency, and contributes to a stabilization of productivity and thereby farm incomes.

\section{Conclusions}

Diversification has to be regarded as a chance for sustainable farming in the Alpine region. In this study, the variable "share of para-agriculture" reflects the multifunctionality of a farm with varied results regarding the impact of diversification activities on agricultural output (i.e., productivity). In Austria and Switzerland, diversification increases agricultural output, which is in turn reinforcing the stability of agricultural production [17]. The data-set does not contain direct information about the potential environmental impacts of diversified farming systems. However, some of the diversification activities are interconnected with public goods and environmental services, such as landscape maintenance or forestry. Other activities like rural tourism foster sustainable consumption. In that sense, diversified organic farming can be seen as an element of sustainable farming strategies for the 21st century [2].

Our results do not clearly recommend diversification as the only economic strategy. The economic impacts of diversification on agricultural output are limited on farms in Southern Germany, where the contribution to total revenue is rather small. Diversification negatively affects the technical efficiency of a farm in Germany and Switzerland, but on the other hand, in Austria diversification contributes to a higher efficiency. These heterogeneous findings show the importance of cross-country studies, since the influences of diversification, particularly on efficiency, are different across countries.

Chavas and Di Falco [18] find incentives for both diversification and for specialization, however with stronger effects of diversification. The results of this study would see advantages of diversification on efficiency and productivity in Austria. Consequently, the more pronounced development of agricultural diversification in Austria might not be astonishing. For Switzerland and Germany, there is no clear answer to the question whether to diversify or specialize, since both strategies bring advantages and drawbacks for farms. Here we find a contribution of diversification to agricultural output that may in the end be outweighed by reduced efficiency in agricultural production, which is in line with the presented literature.

Maintaining agricultural landscapes at marginal production sites is an important objective of agricultural policy [61]. It has been shown that changing economic environments also exhibit an influence on agricultural landscapes [62,63]. Diversification might reduce the risk of farm abandonment in low-productivity marginal regions, and can therefore counteract the loss of open agricultural landscapes as cultural heritage. Our results show that the shadow costs for land (as one input factor) even increase with diversification. Diversification activities on farms in Austria coincide with land use and thereby landscapes. Since landscapes are an important argument for aspects such as rural tourism, diversification is not in contradiction to agricultural land use. This is specifically true for organic farms, since the share of organic farms in the Swiss high alpine regions is significantly higher [7]. For the case of Austria, our results suggest that maintaining typical alpine landscapes as cultural heritage (including moderate agricultural and forestry use) are in line with 'diversified organic farming systems' in high alpine regions.

Finally, we can conclude that direct payments coincide with a lower efficiency of the analyzed farms. This result corresponds to the empirical findings in other studies, that coupled payments negatively influence farmers' decision on input intensities and production program compositions [31-33,64,65]. Coupled payments are still maintained in the CAP after 2013 to a small extent, therefore the results might still contribute to the analysis of actual policies. However, our results also show that payments 
reduce farms' efficiency, even if they are linked to the provision of public goods (with the exception of Austria). This might be a bit surprising, since agri-environmental payments are not directly determining production volume. However, due to its restraining character and links to natural disadvantages, agri-environmental payments have a significant influence on production possibilities, and might therefore also negatively affect farms' technical efficiency.

Acknowledgments: We acknowledge support by the German Research Foundation and the Open Access Publication Funds of the Göttingen University. The authors would like to thank Dierk Schmid for his support in the data preparation and Markus Lips and Stephan von Cramon-Taubadel for their constructive comments on the paper.

Author Contributions: All authors contributed to design, data-preparation, introduction, literature review, results and discussion. The methods-section and the modelling were done by Sebastian Lakner and Bernhard Brümmer.

Note: Please note, that some of the results have been presented on national and international conferences (The Congress of the European Association of Agricultural Economists (EAAE) in Ljubljana, Slovenia 2014, the Conference of the Austrian Society of Agricultural Economists in Prague, Czech Republic 2015, and the German Organic Farming Conference in Eberswalde, Germany 2015) in the form of preliminary conference or discussion papers. The presented results are regarded as final, all remaining errors are our own.

Conflicts of Interest: The authors declare no conflict of interest.

\section{Appendix}

Table A1. Support payments for organic farming in Swiss, Austria, Bavaria and Baden-Württemberg 2003-2005.

\begin{tabular}{|c|c|c|c|c|}
\hline \multicolumn{5}{|c|}{ Premium for Maintaining Organic Farming on Grassland (EUR/ha) } \\
\hline \multirow[b]{2}{*}{ Switzerland } & \multicolumn{2}{|c|}{ Austria } & \multirow[b]{2}{*}{ Baden-Württemberg } & \multirow[b]{2}{*}{ Bavaria } \\
\hline & $\begin{array}{l}\text { Grassland Used Twice/Year } \\
\text { (<1.5 AU/ha) }(>1.5 \mathrm{AU} / \mathrm{ha})\end{array}$ & $\begin{array}{l}\text { Grassland Used Once Per Year } \\
(<1.5 \mathrm{AU} / \mathrm{ha}) \quad(>1.5 \mathrm{AU} / \mathrm{ha})\end{array}$ & & \\
\hline 129 & 160 & 150 & 130 & 255 \\
\hline \multicolumn{5}{|c|}{ Premium for Maintaining Organic Farming on Arable Land (EUR/ha) } \\
\hline Switzerland & \multicolumn{2}{|c|}{ Austria } & Baden-Württemberg & Bavaria \\
\hline 516 & \multicolumn{2}{|c|}{327} & 170 & 255 \\
\hline
\end{tabular}

Source: own presentation from Nieberg et al., 2011 [34]; Ministry for Life Austria [35], Swiss Ministry for Agriculture [57].

\section{References}

1. OECD. Multifunctionality: Executive Summary: Towards an Analytical Framework; OECD: Paris, France, 2001.

2. Reganold, J.P.; Wachter, J.M. Organic agriculture in the twenty-first century. Nat. Plants 2016, $2,15221$. [CrossRef] [PubMed]

3. Wilson, G.A. From 'weak' to 'strong' multifunctionality: Conceptualising farm-level multifunctional transitional pathways. J. Rural Stud. 2008, 24, 367-383. [CrossRef]

4. Schmid, D.; Lenggenhager, P.; Steingruber, E. Economics of Para-Agriculture: The Example of Direct Marketing. 2010. Available online: https://www.agroscope.admin.ch/agroscope/ en/home/publications/publication-search/agroscope-science/_jcr_content/par/externalcontent. external.exturl.pdf/aHR0cHM6Ly9pcmEuYWdyb3Njb3BlLmNoL2VuLVVTL0VpbnplbH/ B1Ymxpa2F0aW9uL0Rvd25sb2FkP2VpbnplbHB1Ymxpa2F0aW9u/SWQ9MjU5MjM=.pdf (accessed on 18 April 2018). (In German)

5. Mamardashvili, P.; Bokusheva, R.; Schmid, D. Heterogeneous farm output and technical efficiency estimates. Ger. J. Agric. Econ. 2014, 63, 16-30.

6. Swiss Ministry for Agriculture. Swiss National Accounting for Agriculture; Swiss Ministry for Agriculture: Bern, Switzerland, 2016. (In German)

7. Flubacher, M. Comparison of the economic performance between organic and conventional dairy farms in the swiss mountain region using matching and stochastic frontier analysis. J. Socio-Econ. Agric. 2015, $8,76-84$. 
8. Reissig, L. Is there more labour on organic family farms? In Proceedings of the Scientific Conference of Organic Farming, Eberswalde, Germany, 17-20 March 2015; University of Applied Science: Berlin, Germany, 2015. (In German)

9. Recke, G.; Zenner, S.; Wirthgen, B. Situation and Perspectives of Direct Marketing in Germany; Landwirtschaftsverlag: Münster Hiltrup, Germany, 2004. (In German)

10. Purdy, B.M.; Langemeier, M.R.; Featherstone, A.M. Financial performance, risk, specialization. J. Agric. Appl. Econ. 1997, 29, 149-161. [CrossRef]

11. Mishra, A.K.; El-Osta, H.S.; Johnson, J.D. Factors contributing to earnings success of cash grain farms. J. Agric. Appl. Econ. 1999, 31, 623-637. [CrossRef]

12. Weiss, C.; Thiele, H. Diversification and growth of agricultural enterprises. Ger. J. Agric. Econ. 2002, 51, 156-163. (In German)

13. Chaplin, H.; Davidova, S.; Gorton, M. Agricultural adjustment and the diversification of farm households and corporate farms in central europe. J. Rural Stud. 2004, 20, 61-77. [CrossRef]

14. Katchova, A.L. The farm diversification discount. Am. J. Agric. Econ. 2005, 87, 984-994. [CrossRef]

15. Barnes, A.P.; Hansson, H.H.; Manevska, T.G.; Shrestha, S.; Thomson, S.G. The Influence of Diversification on Short-Term and Long-Term Viability in the Scottish and Swedish Agricultural Sector. 2014. Available online: https:/ / ageconsearch.umn.edu/bitstream/182654/2/Barnes-The_influence_of_diversification_on_ long-term_viability-138_a.pdf (accessed on 18 April 2018).

16. Khanal, A.R.; Mishra, A.K. Agritourism and off-farm work: Survival strategies for small farms. Agric. Econ. 2014, 45, 65-76. [CrossRef]

17. Schilling, B.J.; Attavanich, W.; Jin, Y. Does agritourism enhance farm profitability. J. Agric. Resour. Econ. 2014, 39, 69-87.

18. Chavas, J.-P.; Di Falco, S. On the role of risk versus economies of scope in farm diversification with an application to ethiopian farms. J. Agric. Econ. 2012, 63, 25-55. [CrossRef]

19. Mamardashvili, P.; Schmid, D. Performance of swiss dairy farms under provision of public goods. Agric. Econ. 2013, 59, 300-314. [CrossRef]

20. Sipiläinen, T.; Huhtala, A. Opportunity costs of providing crop diversity in organic and conventional farming: Would targeted environmental policies make economic sense? Eur. Rev. Agric. Econ. 2013, 40, 441-462. [CrossRef]

21. Bowman, M.S.; Zilberman, D. Economic factors affecting diversified farming systems. Ecol. Soc. 2013, 18. [CrossRef]

22. McNally, S. Farm diversification in england and wales-what can we learn from the farm business survey? J. Rural Stud. 2001, 17, 247-257. [CrossRef]

23. Meert, H.; Van Huylenbroeck, G.; Vernimmen, T.; Bourgeois, M.; van Hecke, E. Farm household survival strategies and diversification on marginal farms. J. Rural Stud. 2005, 21, 81-97. [CrossRef]

24. Mishra, A.K.; El-Osta, H.S.; Sandretto, C.L. Factors affecting farm enterprise diversification. Agric. Financ. Rev. 2004, 64, 151-166. [CrossRef]

25. Pfeifer, C.; Jongeneel, R.A.; Sonneveld, M.P.W.; Stoorvogel, J.J. Landscape properties as drivers for farm diversification: A dutch case study. Land Use Policy 2009, 26, 1106-1115. [CrossRef]

26. Eder, M. Organic farming in austria: A success story. In Festschrift for Prof. Schneeberger-Alternative Strategies for Agriculture; Darnhofer, I., Wytrzens, H.K., Walla, C., Eds.; Facultas: Vienna, Austria, 2006; pp. 89-100. (In German)

27. Ilbery, B.W. Farm diversification as an adjustment strategy on the urban fringe of the west midlands. J. Rural Stud. 1991, 7, 207-218. [CrossRef]

28. Swinnen, J.F.M. The Perfect Storm-The Political Economy of the Fischler Reforms of the Common Agricultural Policy; Centre for European Policy Studies (CEPS): Brussels, Belgium, 2008.

29. OECD. OECD Review of Agricultural Policies: Switzerland 2015; Organization for Economics Cooperation and Development (OECD): Paris, France, 2015.

30. BMELF. Agenda 2000-Crop Production and Agri-Environmental Programs; Federal Ministry for Food, Agriculture and Forestry in Germany (BMELF): Bonn, Germany, 2000. (In German) 
31. Henningsen, A.; Kumbhakar, S.C.; Lien, G. Analysis of the effects of subsidies on farm production in case of endogenous input quantities. In Proceedings of the European Association Agricultural Economists (EAAE) 2011 Congress, Zürich, Switzerland, 30 August-2 September 2011; European Association Agricultural Economists (EAAE): Zürich, Switzerland, 2011.

32. McCloud, N.; Kumbhakar, S.C. Does subsidy drive productivity? A cross-country analysis of nordic dairy farms. In Advances in Econometrics; Chib, S., Griffiths, W., Koop, G., Terrell, D., Eds.; Emerald Group: Bingley, UK, 2008; Volume 23, pp. 245-274.

33. Minviel, J.J.; Latruffe, L. Effect of public subsidies on farm technical efficiency: A meta-analysis of empirical results. Appl. Econ. 2016. [CrossRef]

34. Nieberg, H.; Kuhnert, H.; Sanders, J. Support of Organic Farming in Germany-Status, Development and International Perspective, 2nd ed.; Thünen Institute for Farm Economics: Braunschweig, Germany, 2011. (In German)

35. BMLFUW. Agricultural Report Incl. Tab. Appendix (Issues 2002 to 2006); Ministry for Agriculture, Forestry, Environment and Water (BMLFUW): Vienna, Austria; Available online: https://gruenerbericht.at (accessed on 18 April 2018). (In German)

36. Schwarz, G.; Nieberg, H.; Sanders, J. Organic Farming Support Payments in the EU (Report); Thünen Institute for Farm Economics: Braunschweig, Germany, 2010.

37. Färe, R.; Primont, D. Multi-Output Production and Duality: Theory and Applications; Kluver Academic Publishers: Boston, MA, USA, 1995.

38. Brümmer, B.; Glauben, T.; Thijssen, G. Decomposition of productivity growth using distance functions: The case of dairy farms in three european countries. Am. J. Agric. Econ. 2002, 84, 628-644. [CrossRef]

39. Beltrán-Esteve, M.; Reig-Martínez, E. Comparing conventional and organic citrus grower efficiency in spain. Agric. Syst. 2014, 129, 115-123. [CrossRef]

40. Breustedt, G.; Latacz-Lohmann, U.; Tiedemann, T. Organic or conventional? Optimal dairy farming technology under the eu milk quota system and organic subsidies. Food Policy 2011, 36, 223-229. [CrossRef]

41. Farrell, M.J. The measurement of productive efficiency. J. R. Stat. Soc. Ser. A 1957, 120, 253-278. [CrossRef]

42. Aigner, D.; Lovell, C.A.K.; Schmidt, P. Formulation and estimation of stochastic frontier production function models. J. Econ. 1977, 6, 21-37. [CrossRef]

43. Lakner, S.; von Cramon-Taubadel, S.; Brümmer, B. Technical efficiency of organic pasture farming in germany: The role of location economics and of specific knowledge. Renew. Agric. Food Syst. 2012, 27, 228-241. [CrossRef]

44. Tiedemann, T.; Latacz-Lohmann, U. Development of productivity in organic and conventional agriculture: An empirical analysis. Ger. J. Agric. Econ. 2011, 60, 101-118. (In German)

45. Battese, G.E.; Rao, D.S.P.; O'Donnell, C. A metafrontier production function for estimation of technical efficiencies and technology gaps for firms operating under different technologies. J. Prod. Anal. 2004, 21, 91-103. [CrossRef]

46. O’Donnell, C.J.; Rao, D.S.P.; Battese, G.E. Metafrontier frameworks for the study of firm-level efficiencies and technology ratios. Empir. Econ. 2008, 34, 231-255. [CrossRef]

47. Holtkamp, J.; Brümmer, B. Stochastic Frontier Analysis Using Sfamb for OX (Software-Manual); University of Göttingen, Department for Agricultural Economics and Rural Development: Göttingen, Germany, 2015.

48. Doornik, J.A.; Hendry, D.F. Modelling Dynamic Systems Using Pcgive (Volume I to Iii); Timberlake Consultants Press: London, UK, 2013.

49. Brümmer, B. Basics of Stochastic Frontier Analysis; Lecture Material, University of Göttingen, Department for Agricultural Economics and Rural Development: Göttingen, Germany, 2006.

50. Kodde, D.A.; Palm, F.C. Wald criteria for jointly testing equality and inequality restrictions. Ecnonometrica 1986, 54, 1243-1248. [CrossRef]

51. Kumbhakar, S.C. Specification and estimation of multiple output technologies: A primal approach. Eur. J. Oper. Res. 2013, 231, 465-473. [CrossRef]

52. Jan, P.; Lips, M.; Dumondel, M. Technical efficiency of swiss dairy farms located in the mountain area considering both economic and environmental resources. Yearb. Socioecon. Agric. 2010, 2010, 39-76.

53. Ferjani, A.; Flury, C. Wie Effizient Sind Bio-Milchbetriebe im Schweizer Berggebiet? Available online: http:/ / orgprints.org/14119/1/Ferjani_14119.pdf (accessed on 18 April 2018). 
54. BMLF. Special Regulation for the Austrian Program to Support Environmental Friendly, Extensive Agriculture Supporting Natural Habitats; Federal Ministry for Agriculture and Forestry in Austria (BMLF): Vienna, Austria, 2000.

55. MLR. Regulation for Support of the Maintenance and Protection of Cultural Landscape and for Production to Relief Markets of 12.09.2000; State Ministry for Rural Areas in Baden-Württemberg (MLR): Stuttgart, Germany, 2000.

56. Swiss Ministry for Agriculture. Agricultural Report 2003; Swiss Federal Ministry for Agriculture: Bern, Switzerland, 2003. (In German)

57. ART. Ex-Post Evaluation of Programs for Plans to Develop Rural Areas in Bavaria between 2000 and 2006; Research Group Agricultural and Regional Development Triesdorf (ART): Triesdorf, Germany, 2008. (In German)

58. Darnhofer, I.; Schneeberger, W. Impacts of voluntary agri-environmental measures on Austria's agriculture. Int. J. Agric. Resour. Govern. Ecol. 2007, 6, 360-377. [CrossRef]

59. Mayen, C.D.; Balagtas, J.V.; Alexander, C.E. Technology adoption and technical efficiency: Organic and conventional dairy farms in the united states. Am. J. Agric. Econ. 2010, 92, 181-195. [CrossRef]

60. Sauer, J.; Walsh, J.; Zilberman, D. Agri-environmental policy effects at producer level-Identification and measurement. Schr. Gesellsch. Wirtsch. Sozialwissensch. Landbaues 2014. Available online: https:/ /ageconsearch. umn.edu/bitstream/156099/2/A4-Sauer-Agri_c.pdf (accessed on 18 April 2018).

61. Plankl, R.; Weingarten, P.; Nieberg, H.; Zimmer, Y.; Isermeyer, F.; Krug, J.; Haxsen, G. Quantifying Public Goods by Agriculture -Desired by Society but Not Assigned with Market Values; Thünen Instutite for Agricultural Economics: Braunschweig, Germany, 2010. (In German)

62. Heißenhuber, A.; Kantelhardt, J.; Schaller, J.; Magel, H. Visualisierung und bewertung ausgewählter landnutzungsentwicklungen. Nat. Landsch. 2004, 79, 159-166.

63. Kapfer, M.; Ziesel, S.; Kantelhardt, J. Modelling individual farm behaviour and landscape appearance. Landsc. Res. 2015, 40, 530-554. [CrossRef]

64. Lakner, S. Technical efficiency of organic milk-farms in germany-The role of subsidies and of regional factors. In Proceedings of the Congress of the International Association of Agricultural Economists Conference (IAAE), Beijing, China, 16-22 August 2009.

65. Latruffe, L.; Bravo-Ureta, B.E.; Carpentier, A.; Desjeux, Y.; Moreira, V.H. Subsidies and technical efficiency in agriculture: Evidence from european dairy farms. Am. J. Agric. Econ. 2016, 99, 783-799. [CrossRef] 